American Journal of Agricultural and Biological Sciences 4 (2): 110-117, 2009

ISSN 1557-4989

(C) 2009 Science Publications

\title{
Investigation of the Agricultural Water Management Mechanisms in Zarindasht County, Fars Province, Iran
}

\author{
Ali Asadi, Yaser Mohammadi and Hossein Shabanali Fami \\ Department of Agricultural Extension and Education, \\ College of Agricultural Economics and Development, University of Tehran, Karaj, Iran
}

\begin{abstract}
Problem statement: Both sequential droughts and lack of water optimal consumption in Zarindasht county, have created scarcity problem that caused agricultural yield's loss in this county. So according to lack of optimal consumption of agricultural water in this county, the main purpose of this study was to investigate agricultural water management mechanisms in three fields of irrigation sources, water transfer and in farm water consumption level. Approach: This study was a sort of survey studies. Questionnaire was used to collect data and its reliability was confirmed by Cronbach's alpha of $0.83,0.72$ and 0.85 in three fields of irrigation resources, water transfer and in farm water consumption level respectively. Questionnaire's validity was also confirmed by professors of agriculture training department of Tehran University and experts were related to water management. Statistical population of this study consisted of 4648 individuals of Zarindasht farmers. Using Cochran's formula, sample size was estimated about 150 individuals. To select the samples, the multistep sampling method was used. Results: The results of priority setting of the agricultural water management mechanisms revealed that most of important mechanisms of agricultural water management such as "feeding underground water", "farmers' participation in providing the expenses of electronically wells", "setting systems of determining the permissible Debby" in field of irrigation resources and " participation in different fields" as an important mechanism in the field of water transfer channels and also "using agricultural swages", "land consolidation and consolidation" in water consumption level are the last priorities of farmers point of view. Furthermore, the result of agricultural water management mechanisms' factor analysis indicated the existence of six factors in irrigation resources field that most important factor was the factor of agricultural knowledge increase. In channels field, five factors were stated that most important of them was channels management. Five other factors were identified in farm water consumption level that the most important one was paying attention to training and extension. Conclusion: To achievement agricultural water management, some management mechanisms such as land consolidation, promotion of farmers' awareness through extension and education methods, canals management and farmers participation to conservation of irrigation networks, were necessary.
\end{abstract}

Key words: Mechanisms, Agricultural water management, Irrigation resource, Farm water consumption level, Zarindasht city

\section{INTRODUCTION}

Nowadays the ascending rate of increasing of world's population and limitation of natural resources in the other hand make the man to seeking solutions and making various decisions to saving and using these resources more efficiently. Water is one of the most necessary needs of human being. Even though water occupied around two third of earth surface, but because of its chronological and local limitation and the low volume of fresh accessible waters in the other hands, water management and planning is an inevitable matter. This is so important that some of the scientists consider the future wars as "the water wars" ${ }^{, 22]}$ the gap between water providing capability and excessive demands is critical while the management's mechanisms could not be able to inhibit this unbalance. The mutual understanding's language will turn to enmity's language ${ }^{[20]}$. At present time; water crisis is one of the subjects which is discussed by scientists, researchers and politicians of all countries. Frank Rigers Berman, head of international institute of water, said that about

Corresponding Author: Yaser Mohammadi, Department of Agricultural Extension and Education,

College of Agricultural Economics and Development, University of Tehran, Karaj, Iran 
one forth of world's population faced the water shortage due to physical factors such as natural disasters, excessive utilization of water resources and weak management in agriculture section and this will lead to early dryness of rivers' and underground waters $^{[27]}$. Iran is also located in dry and semi-dry places of the world which their main problem is water shortage $^{[10]}$. Researches showed that about $67 \%$ of water is used in agriculture section and it is amazing that this amount is about $90 \%$ in developing countries like $\operatorname{Iran}^{[29]}$. This indicates the necessity of presenting mechanisms for effective management of agricultural water. The third thousandth anniversary goals to decrease the poverty, hunger and making a sustainable environment, without agricultural water management, will not be accomplished ${ }^{[28]}$. Nowadays, sustainable management of water and land resources is considered as a point of agreement and also an international duty ${ }^{[5]}$. Zarindasht is one of 13 counties of Fars province which encounter water shortage which is a result of long periods of drought and excessive utilization of underground's resources ${ }^{[2]}$. While the agriculture section has a special importance in this county and the main resource of agricultural water in this region is underground water, the annual decrease of underground waters' level is significant because of excessive amount of utilization ${ }^{[17]}$. As agricultural experts of Zarindasht said, agricultural water management of region is dependent on practicable mechanisms to decrease excessive utilization of agricultural water and rational and logical utilization of that to reach the high operation of product. Considering the water crisis and presenting the management's mechanisms to resist water shortage, different studies have been achieved. For example, Heidari ${ }^{[14]}$ thought that improvement and correction of agricultural water management's problems and proper management planning are parts of agricultural water management's mechanisms. Farzampour $^{[9]}$, Jahani ${ }^{[16]}$, Pereira et al. ${ }^{[24]}$ and lots of other researchers believed that increasing the knowledge of society and consumers is effective in agricultural water management.

In other researches, land consolidation and consolidation is considered as important mechanisms of agricultural water management and is mentioned in studies of ${ }^{[3,4,25]}$. Coordination between governments' organization is one of these mechanisms in Davarpanah $^{[6]}$ point of view. Ehasni et al. ${ }^{[7]}$ and Nazemi ${ }^{[23]}$ also believed that participation and establishment of local association are parts of agricultural water management's mechanisms. Underground water feeding is one of the other mechanisms that are pointed out in researches of
Zehtabian $^{[30]}$, Hamedan regional water company public relationship report ${ }^{[10,13]}$. Heidari et al. ${ }^{[15]}$ and Farshi ${ }^{[8]}$ suggested effective training, Extension and research to have a better agricultural water management. In studies of Izuno ${ }^{[1]}$ and Sastri ${ }^{[26]}$ considering farming management as an important of mechanisms of agricultural water management. Moon-Hoon et al. ${ }^{[19]}$ and Jin and Yong ${ }^{[18]}$, also address the agricultural water streams management and using polyethylene pipes as parts of the practicable mechanisms of agricultural water management.

Izuno $^{[11]}$ consider the irrigation construction as a system that consists of water sources, irrigation systems, soil and product's substructures and drainage system. To manage the agricultural water enough attention should be paid to every systems and water resources, transfer systems, farms and drainage should be managed. In this regard, this study investigates the agricultural water management's mechanisms in three fields of water resources, transfer channels and farm water consumption level. The main goal of this study is investigation and analysis of agricultural water management's mechanisms in Zarindasht and follows some specific goals that are as follows:

- Study farmers' social and individual characteristics

- Setting the priorities of agricultural water management's mechanisms of three fields of water resources, channels and farm water consumption level in Zarindasht

- Factor analysis of agricultural water management's mechanisms in three fields of water resources, channels and farm water consumption level

\section{MATERIALS AND METHODS}

The research method of this study is a sort of applied studies with a view to goals. It is a field study with a view to variables' control degree and is correlation-descriptive study with a view to information analysis methods. The study's theoretical framework was gained using librarian study method, electronic resources and field studies of the region. The region in our study was Zarindasht, a city in Fars province, Iran. The statistical population of study is farmers of Zarindasht and includes 4648 rural families of Zarindasht (consists of two divisions, five rural districts and 23 villages of Fars province), selected in two steps. In the first step, stratified sampling method was used and in the second step random sampling method was used to select our samples. Using Cochran's formula, sample size was estimated about 150 individuals. Questionnaire was used to gather the data and 
information. After the pilot studies on farmers, The Cronbach's alpha coefficient was used to compare the mechanisms of agricultural water management in three fields of water resources, channels and farm water consumption level. Their Cronbach's alpha values were $0.83,0.72$ and 0.85 respectively which showed an acceptable reliability. Data analysis was done in tow levels of descriptive statistics (frequency, distribution, percentage, mean and priority setting) and inferential statistics (analysis of variance), using WINSPSS 11.5.

\section{RESULTES}

Professional and individual characteristics: The results showed that the majority of farmers are in middle-aged group (30-60 years old) with mean value of 42 years old. The mean of their agricultural work acquaintance was 16 years old. The results also revealed that, the mean value of farmers' lands under cultivation is 6.5 ha and the average numbers of their lands' fragments is three. About 50\% of their lands have ups and downs and their soil is salty with white patches. According to the findings $95 \%$ of them used deep wells and pipes with average diameter of 4 inches to irrigate their farms. $62 \%$ of wells were located more than one kilometer far away from farms. Most of the farmers had a joint ownership regarding the water resources and $99 \%$ of them utilized the conventional deepwater irrigation method to irrigate the farms. About $31 \%$ of farmers used the combination of land channels and polyethylene pipes to transfer water to farms and about $23 \%$ of them just used the land channels. The average length of water transfer channels is $1.5 \mathrm{~km}$. About $61 \%$ of farmers take advantages of credits to improve their irrigation systems. The water of most farmers was semi-salty and more than $97 \%$ of them lack drainage systems for their lands. $73 \%$ of farmers believe that they face dryness very much.

Setting priority of agricultural water management's mechanisms from farmer's point of view: To determine the underground water management's mechanisms, 45 statements were proposed and farmers were asked to express their views about the performance of every mechanism by giving a number from 1(the least performance in region) to five (the most performance in the region) in a Likert scale. Table 1 shows the priority setting of underground water management's mechanisms from farmer's points of view which are set according to the Coefficient of Variation $(\mathrm{CV})$. Lower $\mathrm{CV}$ indicates the lower variation of farmers' views, that means the lower CV represent more agreement of farmers about the mechanisms. It is clear important mechanisms are those which most of farmers are agreed about them highest mean score (6.84). This implies that most of As the findings in this study shows (Table 1) "using a perfect and safe pump", "observance of distance between wells", "using movement license and constructing a new well" are as the first three priorities of irrigation resources management mechanism which are carried out more than other mechanisms in the region. But according to the farmers' point of view, "simple feeding of underground waters as much as possible", "participation in financial help for electrification of neighboring wells' pumps", "setting equipments to determine the permissible Debby for water exploitation of each well", are the last three priorities regarding their performance in the region. Also, In water transfer field "performance of repair and replacement of cover fragments of channels in different times", "Decreasing water loss by using polyethylene pipes" and "paying attention to channels' capacities and the proportional amount of water being transferred" are as three first priorities with due attention to their performance and the last three priorities include "Preventing the entrance of industrial or domestic swage to water channels", "Farmers' participation in providing expenses to plumbing the common direction to transfer water" and "Farmers' participation in channels and streams' dredging". In farm water consumption level, "Using appropriate amount of water for lands under cultivation", "Attendance in training classes regarding the water transfer methods" and "Performance of cultivation pattern recommended by authorities" are first three priorities of management's mechanisms which are noticed in the region. But "Using the agricultural weakest-water for a second irrigation", "Land consolidation" and "Using salty and fresh water as much as possible" are the last three priorities of water management's mechanisms in farm water consumption level.

Factor Analysis of agricultural water management: To determine the factors of agricultural water management, variables of three fields of irrigation resources, water transfer and in farm water consumption level enter the factor analysis. data fitness according to the KMO statistics and Bartlett's test is shown in Table 2 that indicates the data's fitness for factor analysis.

According to the results shown in Table 3, known factors of agricultural water management's mechanisms in three fields of irrigation resources, water transfer and in farm water consumption level are as follows:

In the field of agricultural irrigation resources' mechanisms, the first factor with special value of 3.31 demonstrates the 22.04 percent of total variance. 
Am. J. Agri. \& Biol. Sci., 4 (2): 110-117, 2009

Table1: Setting priority of agricultural water management's mechanisms from farmer's point of view

\begin{tabular}{|c|c|c|c|c|}
\hline Agricultural water management's mechanisms & Std. & Mean & $\mathrm{CV}$ & Priority \\
\hline \multicolumn{5}{|l|}{ Water resources field: } \\
\hline Using a perfect and safe pump & 0.91590 & 3.9933 & 0.22940 & 1 \\
\hline Observance of distance between wells & 0.97854 & 4.0467 & 0.24180 & 2 \\
\hline Using movement license and constructing a new well & 1.03770 & 4.0600 & 0.25560 & 3 \\
\hline Electrification of well's pumps to use underground waters efficiently & 1.00290 & 3.9133 & 0.25630 & 4 \\
\hline $\begin{array}{l}\text { Increasing knowledge about the salty water as a result of excessive utilization } \\
\text { of water }\end{array}$ & 0.92260 & 3.3667 & 0.27400 & 5 \\
\hline Using underground water according to the land under cultivation & 0.96430 & 3.4200 & 0.28190 & 6 \\
\hline Increasing the skills and information regarding water pumps & 0.99850 & 3.3600 & 0.29720 & 7 \\
\hline $\begin{array}{l}\text { Paying enough attention to research, training and Extension of efficient } \\
\text { utilization of wells' water }\end{array}$ & 1.07530 & 3.3133 & 0.32450 & 8 \\
\hline Being ready to pay for pumps, pipes and increasing well depth & 1.13320 & 3.3800 & 0.33530 & 9 \\
\hline No utilization of well in middle of the day & 1.24600 & 3.0667 & 0.40630 & 10 \\
\hline $\begin{array}{l}\text { Using appropriate tools to measure water consumption of each farmer who has } \\
\text { water pump }\end{array}$ & 1.37780 & 3.3667 & 0.40920 & 11 \\
\hline No utilization of wells with salty water & 1.12520 & 2.6800 & 0.41980 & 12 \\
\hline $\begin{array}{l}\text { Setting equipments to determine the permissible Debby for water } \\
\text { exploitation of each well }\end{array}$ & 1.30070 & 2.8600 & 0.45480 & 13 \\
\hline Participation in financial help for electrification of neighboring wells' pumps & 1.42310 & 2.7800 & 0.51190 & 14 \\
\hline Simple feeding of underground waters as much as possible & 6.96060 & 3.8867 & 1.79090 & 15 \\
\hline \multicolumn{5}{|l|}{ Water transfer field: } \\
\hline $\begin{array}{l}\text { Performance of repair and replacement of cover fragments of channels in } \\
\text { different times }\end{array}$ & 0.87120 & 3.7067 & 0.23500 & 1 \\
\hline Decreasing water loss by using polyethylene pipes & 0.99760 & 3.8933 & 0.25620 & 2 \\
\hline $\begin{array}{l}\text { Paying attention to channels' capacities and the proportional amount of water } \\
\text { being transferred }\end{array}$ & 0.99120 & 3.7467 & 0.26450 & 3 \\
\hline Removal of unnecessary meanders of conventional channels & 0.94460 & 3.5600 & 0.26530 & 4 \\
\hline Regular visits of channels in time & 1.03420 & 3.7600 & 0.27500 & 5 \\
\hline Getting information about water transfer to increase water transfer efficiency & 0.90980 & 3.2667 & 0.27850 & 6 \\
\hline Removal of herbs around the water transfer channels & 1.10570 & 3.8400 & 0.28790 & 7 \\
\hline Covering the channels and streams in places that water transfer is low & 1.20750 & 3.4600 & 0.34900 & 8 \\
\hline Covering polyethylene pipes to prevent their pierced and water loss & 1.29820 & 3.7067 & 0.35020 & 9 \\
\hline Repair of pipes' joints to prevent loss of water due to leakage & 1.27660 & 3.1667 & 0.40310 & 10 \\
\hline Farmers' participation in making water transfer pipes concreted or plumbing & 1.32070 & 3.0867 & 0.42790 & 11 \\
\hline Farmers' participation in channels and streams' & 2.62010 & 3.7400 & 0.70060 & 12 \\
\hline $\begin{array}{l}\text { Farmers' participation in providing expenses to plumbing the common direction } \\
\text { to transfer water }\end{array}$ & 2.83730 & 3.5067 & 0.80910 & 13 \\
\hline \multicolumn{5}{|l|}{ In farm water consumption level: } \\
\hline Creating proportion between amount of water with lands under cultivation & 0.85570 & 3.2933 & 0.25980 & 1 \\
\hline Attendance in extension training classes regarding the water transfer methods & 0.87280 & 3.3000 & 0.26450 & 2 \\
\hline Performance of cultivation pattern recommended by authorities & 0.83340 & 3.1000 & 0.26890 & 3 \\
\hline Using more than one water-distributor at night to prevent water loss & 0.93880 & 3.2667 & 0.28740 & 4 \\
\hline $\begin{array}{l}\text { Attendance in extension training classes regarding effective utilization of water } \\
\text { in farms }\end{array}$ & 0.96200 & 3.3067 & 0.29090 & 5 \\
\hline Using other framers' experiments who used new irrigation systems & 0.94790 & 3.2467 & 0.29200 & 6 \\
\hline Using cultivation alternation to maintain soil moisture & 0.94030 & 3.2200 & 0.29200 & 7 \\
\hline Preventing of irrigation in middle of the day as much as possible decreasing the & 0.94140 & 3.1400 & 0.29980 & 8 \\
\hline length of water channel in farms and between lands & 0.96530 & 3.1667 & 0.30480 & 9 \\
\hline Test the soil to determine the exact mount of water plants need & 1.04390 & 3.2533 & 0.32090 & 10 \\
\hline Using cultivation alternation of dry and juicy products' cultivation & 1.01070 & 3.0733 & 0.32880 & 11 \\
\hline Irrigation according to the products' water need & 0.99980 & 2.9800 & 0.33550 & 12 \\
\hline Utilization of irrigation systems according to the region recommended by experts & 1.03950 & 2.9933 & 0.34730 & 13 \\
\hline Using salty and fresh water as much as possible & 1.06960 & 3.0600 & 0.34950 & 14 \\
\hline Land consolidation & 1.19090 & 3.0667 & 0.38840 & 15 \\
\hline Using the agricultural weakest-water for a second irrigation & 0.98080 & 2.3800 & 0.41210 & 16 \\
\hline
\end{tabular}

Table 2: value of KMO statistics and Bartlett's test

\begin{tabular}{|c|c|c|c|c|}
\hline Factor analysis & & KMO & Bartlet test & Sig \\
\hline \multirow[t]{3}{*}{ Agricultural water management's mechanisms } & Irrigation resources field & 0.782 & 824.274 & 0.000 \\
\hline & Water transfer & 0.793 & 704.502 & 0.000 \\
\hline & In farm water consumption level & 0.752 & 621.282 & 0.000 \\
\hline
\end{tabular}


Am. J. Agri. \& Biol. Sci., 4 (2): 110-117, 2009

Table3: extracted factors with special value, variance percentage and their cumulative variance percentage

\begin{tabular}{|c|c|c|c|c|}
\hline Fields & Factors & Special value of special value & Variance percentage variance percentage & Cumulative \\
\hline \multirow[t]{5}{*}{ Irrigation resources } & 1 & 3.31 & 22.04 & 22.04 \\
\hline & 2 & 2.25 & 15.00 & 37.04 \\
\hline & 3 & 1.90 & 12.67 & 49.72 \\
\hline & 4 & 1.42 & 9.45 & 59.18 \\
\hline & 5 & 1.35 & 9.03 & 68.20 \\
\hline \multirow[t]{4}{*}{ Water transfer } & 1 & 3.06 & 21.84 & 21.84 \\
\hline & 2 & 2.39 & 17.09 & 38.92 \\
\hline & 3 & 2.03 & 14.48 & 53.40 \\
\hline & 4 & 1.40 & 10.01 & 63.41 \\
\hline In farm water & 1 & 3.04 & 21.75 & 21.75 \\
\hline \multirow[t]{3}{*}{ consumption level } & 2 & 2.59 & 16.20 & 37.95 \\
\hline & 3 & 2.53 & 15.79 & 53.74 \\
\hline & 4 & 1.56 & 9.72 & 63.46 \\
\hline
\end{tabular}

Table 4: determination of factors related to agricultural water management's methods, statements and related Eigen

\begin{tabular}{|c|c|c|c|}
\hline Field & Factor name & variables & Eigen values \\
\hline Water & Increasing management's & Using appropriate tools to measure water consumption of each farmer who has water pump & 0.7930 \\
\hline \multirow[t]{14}{*}{ resources } & \multirow{5}{*}{$\begin{array}{l}\text { knowledge and skills of } \\
\text { farmers }\end{array}$} & Increasing farmers' knowledge and skills regarding maintenance and servicing of pumps stations & 0.7510 \\
\hline & & Using a perfect and safe pumps & 0.6790 \\
\hline & & Making farmers be able to determine received water volume in places of water distribution & 0.6240 \\
\hline & & Increasing knowledge about salty water of wells as a result of excessive use of water & 0.5790 \\
\hline & & Paying attention to extension recommendation related to well's water utilization and management & 0.4350 \\
\hline & \multirow{3}{*}{$\begin{array}{l}\text { Underground water resources' } \\
\text { protection }\end{array}$} & No utilization of pumps in middle of the day & 0.8110 \\
\hline & & Simple feeding of underground waters & 0.6 .76 \\
\hline & & Using underground waters according to the lands under cultivation & 0.6350 \\
\hline & \multirow{6}{*}{$\begin{array}{l}\text { Farmers' responsibility } \\
\text { regarding the laws } \\
\text { Participation of effective } \\
\text { utilization of irrigation } \\
\text { underground resources } \\
\text { Follow the laws and standards }\end{array}$} & Using movement license and constructing a new well & 0.7970 \\
\hline & & No utilization of wells with salty water & 0.6560 \\
\hline & & Electrification of well's pumps & 0.7310 \\
\hline & & Being ready to pay for pumps, pipes and increasing well depth & 0.6830 \\
\hline & & Farmers' participation in providing the expenses for electrification of pumps of joint wells & 0.5840 \\
\hline & & Observance of distance between wells & 0.6470 \\
\hline \multirow[t]{11}{*}{$\begin{array}{l}\text { Water } \\
\text { transfer }\end{array}$} & & $\begin{array}{l}\text { Paying attention to channels' capacities and the proportional amount } \\
\text { of water being transferred }\end{array}$ & 0.7790 \\
\hline & & Repair of pipes' joints to prevent loss of water due to leakage 0.747 & \\
\hline & \multirow{3}{*}{ Channels maintenance } & Removal of herbs around the water transfer channels & 0.6160 \\
\hline & & Covering polyethylene pipes to prevent their pierced and water loss & 0.6000 \\
\hline & & Removal of unnecessary meanders of conventional channels & 0.5050 \\
\hline & \multirow{3}{*}{$\begin{array}{l}\text { Farmers' participation in } \\
\text { water transfer projects }\end{array}$} & Farmers' participation in making water transfer pipes concreted or plumbing & 0.8230 \\
\hline & & Farmers' participation in channels and streams' dredging & 0.8080 \\
\hline & & Farmers' participation in providing expenses to plumbing the common direction to transfer water & 0.6670 \\
\hline & \multirow{2}{*}{$\begin{array}{l}\text { Channels technical and } \\
\text { physical improvement }\end{array}$} & Decreasing water loss by using polyethylene pipes & 0.8110 \\
\hline & & $\begin{array}{l}\text { Performance of repair and replacement of cover fragments of } \\
\text { channels in suitable different times }\end{array}$ & 0.5770 \\
\hline & External factors' control & Preventing the entrance of industrial or domestic swage to water channels & 0.8340 \\
\hline \multirow{15}{*}{$\begin{array}{l}\text { In farm's } \\
\text { consumption } \\
\text { level }\end{array}$} & \multirow[t]{5}{*}{ Training and extension } & Attendance in extension training classes regarding effective utilization of water in farms & 0.8160 \\
\hline & & Attendance in extension training classes regarding water transfer methods & 0.7210 \\
\hline & & Follow the cultivation pattern recommended by experts and authorities decreasing the length & 0.6340 \\
\hline & & of water channel in farms and between lands & 0.5300 \\
\hline & & Utilization of irrigation systems according to the region recommended by experts & 0.4230 \\
\hline & \multirow[t]{3}{*}{ Soil and water management } & Using other farmers' experiments who used new irrigation systems & 0.8250 \\
\hline & & Creating proportion between amount of consuming water with lands under cultivation & 0.7400 \\
\hline & & Using alternative cultivation of dry and juicy products & 0.5010 \\
\hline & \multirow[t]{5}{*}{ Quality improvement } & No utilization of water in middle of the day & 0.7260 \\
\hline & & Using both salty and fresh water as much as possible & 0.6950 \\
\hline & & Land consolidation & 0.6080 \\
\hline & & Irrigation as much as needed for products & 0.5940 \\
\hline & & Using the agricultural weakest-water for second irrigation & 0.5790 \\
\hline & \multirow[t]{2}{*}{ Farm's management } & Using more than one water-distributor at night to prevent water loss & 0.7450 \\
\hline & & Test the soil to determine the exact mount of water plants need & 0.7250 \\
\hline
\end{tabular}

As a whole, the five factors demonstrate 68.83 percent of total variance which indicates that a high level of variance are demonstrated by these factors. In the same manner, four factors was determined in water transfer field which demonstrate $63.41 \%$ of total variance. Finally, four factors was recognized in farm water consumption level which demonstrate 63. Forty six percent of total variance. Variables' positions, assuming that variables with factor load of more than 0.5 , after rotation of factors via Varimax method and factors' nomenclature is shown in Table 4.

The results of Table 4 indicated that, there are 5 factors including Increasing management's knowledge and skills of farmers, Underground water resources' protection, Farmers' responsibility regarding the laws, Participation of effective utilization of irrigation 
underground resources, follow the laws and standards in water's resources conservation field and 4 factors including Channels maintenance, Farmers' participation in water transfer projects, Channels technical and physical improvement, External factors' control in water transfer field. Also according to results of Table 4, there are 4 factors in farm's consumption field including Training and Extension, Soil and water management, Quality improvement, Farm's management.

\section{DISCUSSION}

According to results of farmers professional and individual characteristics, first in one hand, the average number of agricultural land's fragments is three and in other hand the majority of farmers agricultural lands have an up and down situation. Therefore the amount of water loss is high and then to access optimal consumption of agricultural water, should use management mechanisms such as land consolidation and integration. But to achievement land consolidation, government has to support farmers in financial and credit manner. Second the majority of farmers use soil canals to water transfer while the length of irrigation canals in the majority cases is more than 1 kilometer, then according to both soil canals and their excessive length from irrigation sources to field, the irrigation efficiency is low because soil canals have high penetration and evaporation. Therefore to achievement optimal water transfer should apply management mechanisms such as using of cement canals or polyethylene pipes to transfer of water. also what priority setting of agricultural water management's mechanisms showed is that in farmers' opinions lots of these mechanisms which are so important for agricultural water management are considered as the last priorities with due attention to their performance. These mechanisms are "feeding underground waters", "participation in financial help for electrification of neighboring wells' pumps" and "setting equipments to determine the permissible Debby for water exploitation of each well" in irrigation resources field. Furthermore "farmers' financial participation" as an important mechanism in channels field and "using agricultural weakest-water along with land consolidation" are ignored. Regarding the dryness problem in the world, specially in Iran which is a dry country because of its low rainfall average, the maintenance and replacement of underground waters as agricultural fresh water resources are so important. Therefore, artificial feeding of underground waters is one of mechanisms which should be persuaded by authorities.
In the other hand, farmers' participation in different affairs such as channels maintenance and development is necessary to prevent the water loss during the transfer. The water which is extracted with so many difficulties and reach the farms should be utilized effectively via a powerful management. So, land consolidation and using the agricultural weakestwater is parts of important mechanisms that farmers and authorities should pay enough attention to them. It is hopped that authorities care these problems.

The results of factor analysis of agricultural water management's mechanisms revealed that in irrigation resources field, the most important factor is related to the mechanism of increasing farmers' management knowledge and skills which is in agreement with studies of ${ }^{[9,15,16,23,24]}$, also in field of water transfer, the most important mechanism is related to factor of channels maintenance which confirmed the researches of ${ }^{[14,18]}$. In farm water consumption level, paying attention to training, Extension and researches is considered as the most important mechanism which is concordant with studies of ${ }^{[7,8,15,30]}$.

\section{CONCLUSION}

- While the "land consolidation" mechanism is the last priority in the farm water consumption level. So, it is recommended that authorities provide required facilities for land consolidation this is in agreement with the findings of ${ }^{[1,3,21]}$ and Hamadan regional water company public relationship report $^{[13]}$

- While "using movement license and constructing a new well" is one of the first priorities of agricultural water management's mechanisms from farmers' point of view, "not closing the illegal wells" is one of the last priorities of water management's mechanisms from experts' point of view. Therefore increasing the number of wells lead to excessive utilization of water. It is suggested that experts pay enough attention and just give the permission of a new well construction when the previous well is completely closed

- According to the results of the study, farmers' participation in providing expenses of plumbing in common water transfer routs and their participation in channels and streams' dredging are the last priorities of water management's mechanisms in water transfer field. Furthermore the results of factor analysis revealed that participation factor is so important in water transfer field is so important. Therefore it is recommended that enough attention be paid to farmers' participation and public 
organization. This is confirmed by studies of ${ }^{[6,7,14,23,24]}$

- Most of the farmers didn't use drainage and in the other hand, using the agricultural weakest-water to irrigate again is one of the last priorities of agricultural water management's mechanisms in farm water consumption level from farmers' point of view. Therefore it is suggested that more attention be paid to drainage and using agricultural weakest-water. This is similar to findings of ${ }^{[11,16,18,19]}$

- The results of factor analysis of agricultural water management's mechanisms in irrigation field showed that increasing farmers' management knowledge and skills is the most important mechanism. It is recommended that brochures, radio, TV programs and training classes be applied to increase farmers' knowledge and skills.

- According to results of factor analysis of agricultural water management's mechanisms in farm water consumption level, the first factor which is training and Extension is the most important mechanisms. So, it is recommended that more attention be paid to training and Extension factor which will lead to effective management of agricultural water. This is also in concordance with findings of ${ }^{[4,8,15]}$ and Golestan and Mazandran regional water organizations' report ${ }^{[12]}$

\section{ACKNOWLEDGEMENT}

Here I express my sincere thanks to the "research and planning assistant of natural resources and agriculture department of Tehran University" which providing financial credits to support this project as a research plan (type six).

\section{REFRENCES}

1. Alizadeh, A., 2001. Drought and need to increase water productivity, dryness and drought publication, No. 2, pp: 3-8.

2. Ansarifar, S., 2006. Thirteen cities of Fars province have water guarantee problem. Sanitation and water corporation of Fars province, Iran. http://www.qudsdaily.com/archive/1385/html/5/13 85-05-19/page1.html\#5

3. Arjomandi, R., F. GHaysardehi and A. Nagafi, 2000. The effect of agricultural exploitation systems changes on water management. Proceeding of the Article Collection of Technical Workshop on Farmers Participation in Irrigation Network Management, Proceeding of the 27th Aban Season, pp: 1-4. http://www.irncid.org/workshop/pdf/W15pdf/3arj mandi.pdf
4. Assareh, A., B. Motamedi and H. Illkhaszadeh, 2006. To compare of integrated and nonintegrated farms irrigation efficiency in Dez irrigation network. Proceeding of the Conference on Iranian National Committee on Irrigation and Drainage, the University of Ahvaz Shahid Chamran, Water Sciences Engineering College, Ahvaz, Iran. http://www.irncid.org/Articles.Aspx?ZID=28

5. Barthle, R. et al., 2005. Comparison of tools for integrated assessment and management of groundwater resources in different river basins with special regard to sustainability. http://www.cosis.net/abstracts/EGU05/03162/EGU 05-J-03162.pdf

6. Davarpanah, G.H., 2001. Investigating the most important of economical and social effects of drought and government assistant mechanisms to reduce these effects. Proceeding of the Conference on Investigating Mechanisms to Dominate with Water Scarcity, Zabol University, Sistan and Baluchestan province, Iran. http://www.esnips.com/SharedFolderAction.ns;jsessioni d=69E29FC1C1482CBE83D8CED1FCC4914C

7. Ehsani, M. and H. KHaledi, 2003. Agricultural water productivity. Iranian National Committee on Irrigation and Drainage Press, Tehran, Iran. http://www.adinebook.com/gp/product/9646668496

8. Farshi, A., 2005. The optimal consumption of agricultural water. Proceeding of the $1 \mathrm{st}$ Conference on Investigating Drainage, Irrigation Network Challenges and Agricultural Water Optimal Consumption, Tehran, Iran. http://www.esnips.com/SharedFolderAction.ns

9. Farzampour, A., 2001, investigating challenges of Iran water recourses management. Budget Prog. J., 6: 8-12.

10. Forooghi, F., A. Mohsenkhani and M. Karimi, 2006. Investigation the circumstance of Fassarud (Darab county, Fars province) region water recourses in resent drought. Payam-E-Ab Pub., 4: 65-68.

11. Izuno, F.T., 2002. Principles of on-form water management. Florida Cooperative Extension Services, Institute of Food and Agriculture Sciences, University of Florida. http://edis.ifas.ufl.edu/pdffiles/AE/AE09900.pdf

12. Golestan Regional Water Company Report, 2006. The mechanisms to increase irrigation efficiency in agricultural sector. Iran Water Tooba Network. http://www.wnn.ir.html.index.php?name=sections $\&$ req $=$ view article $\&$ article $=38$ page $=1$ 
13. Hamadan Regional Water Company public Relationships Report, 2006. To strengthen of groundwater aquifers. Payam-E-Ab Pub., 4: 29-30.

14. Haydari, N., 2006. Water productivity in Iran agriculture, Barzgar animal and agriculture publication. appendix of No. 955. pp: 43-45.

15. Haydari, N., A. Eslami, A. GHadami Firoozabadi, A. Kanooni, M. Esmaeel Asadi and M. Khajeabdollahi, 2005. water consumption efficiency of agricultural production in Iran different regions (Kerman, Hamadan, Semnan, Golestan and KHoozestan provinces). Proceeding of the Article Collection of Iranian National Committee on Irrigation and Drainage Conference, Water Sciences Engineering College, Ahvaz, Iran. http://www.irncid.org/Articles.Aspx?ZID=28

16. Jahani, A., 2005. Water security and demand management. The article collection of 10th conference of Iranian National Committee on Irrigation and Drainage, Tehran, Iran. http://www.irncid.org/seminars/10.htm

17. Jihad-E-Agriculture Management of Zarindasht county, 2006. Fars province, Iran, http://www.jkzarindasht.ir/khosoye.phtml

18. Jin, L. and W. Yong, 2001. Water use in agriculture in China: Importance, challenges and implications for policy. Water Policy, 3: 215-228.

19. Koh, M.H. et al., 2002. Status of agricultural water in Korea: Water use and water quality. National Institute of Agricultural Science and Technology (RDA), Korea.

http://webdomino1.oecd.org/comnet/agr/water.nsf/ viewHtml/index/\$FILE/6-Mun-Hwan.pdf

20. Mahab GHodss Consulting Engineering Company, 2006. The advisor researches to assignment water economical value in agricultural consumption. The 1st Mid-work report, Technical Document Center.

21. Mahdavi, M., 2005. The role of management in irrigation water optimal consumption. Proceeding of the 10th Conference on Iranian National Committee on Irrigation and Drainage, Tehran, Iran. http://www.irncid.org/seminars/10.htm

22. Nagafpour, B., 2000, Middle East water critical recourses. Sepehr Pub., 9: 22-51.
23. Nazemi, A., 2005. Water resourses sustainabale development, integrated management aspects, investigating mechanisms to dominate with water scarcity conference. Zabol University, Sistan and Baluchestan province, Iran. http://www.esnips.com/web/rahkareaab?docsPage= 1\#files

24. Pereira, L.S., T. Oweis and A. Zairi, 2002. Irrigation Management under water scarcity. Agric. Water Manage., 57: 175-206.

25. Saadat, H. and M. Mahdavi, 2001. The optimal management of water in Sistan and Baluchestan province. Proceeding of the Conference on Investigating Mechanisms to Dominate with Water Scarcity, Zabol University, Sistan and Baluchestan province, Iran.

http://www.esnips.com/web/rahkareaab?docsPage= 2\#files

26. Sastri, A.S.R.A.S., 2000. Agricultural Drought Management for Sustained Agricultural Development. In: Drought: A Global Assessment, Wilhite, D.A. (Ed.). pp: 32-58.

27. Sistan and Baluchestan Regional Water Company Report, 2006. The water scarcity influence on one person from three person. http://www.sbrw.ir/default.asp?nw=news

28. Molden, D., 2007. Water for food-Water for life, A Comprehensive Assessment of Water Management in Agriculture. Published by International Water Management Institute, pp: 688. http://www.earthscan.co.uk/?tabid=627

29. Earth Day Network, 2003. Water and agriculture. http:www.earthday.net.media.earthday.pdf.progra ms.water-agriculture.pdf

30. Zehtabiyan, G.H., 2005. The causes of low irrigation efficiency in Varamin region. Proceeding of the 7th Seminar of Iranian National Committee on Irrigation and Drainage. Tehran, Iran. http://www.irncid.org/seminars/7.htm 